\title{
Study on the Application of Batik Technique on Fashion Design
}

\author{
Xing Zhong ${ }^{1}$ \\ ${ }^{1}$ Jiangxi Institute of Fashion Technology, Nanchang, Jiangxi, 330201
}

KEYWORDS: Batik Technique; Costume Design; Art Style

\begin{abstract}
Batik is China's traditional textile dyeing process and is one of the three major ancient printing techniques in China. Batik patterns rich, elegant colors, forming a simple and generous, fresh and pleasing style, rather ethnic characteristics. Batik art is an important part of ancient Chinese ethnic minority art. With the rapid development of China's garment industry, many designers continue to seek new clothing design elements. Batik art as a unique national characteristics of the process more and more welcomed by everyone and attention, it's deep and rich cultural connotations meaning attracted everyone's attention. With the rapid development of technology, textile technology has also greatly improved, batik also generally use to clothing design and production. This paper describes batik skills overview and batik techniques artistic style, focusing on analysis of the batik art application background and rationality, to explore how to be innovative in the traditional batik techniques on enhancing their aesthetic and usability, promote rapid and healthy development of modern batik technique, in order to provide reference for the cultural heritage of traditional costumes and rich diversity of modern dress.
\end{abstract}

\section{Introduction}

Batik is the traditional dyeing process of the Miao, Buyi and other ethnic groups with a long history, it has flourished in Guizhou, Sichuan and other places. Batik has a unique culture, heritage a long time. However, due to the complex production process and the development of modern printing technology, batik with changing times and gradually decline, the process lapses heritage, batik technology products on the market gradually shoddy, simple single patterning process, its unique cultural ideology are gradually disappear, this great heritage and is not conducive to the development of batik skills. Now present, China's relevant departments and civil society organizations began to focus on the protection and study of batik technique, attention to culture and artistic characteristics of batik skills and strengthen batik skills improvement and innovation, which is our country's batik process in modern costumes It provides a good use of the theoretical and technical basis. Now present, to pursue diversification of clothing, fashion show at home and abroad in the use of minority elements in common, sought after by many fashion designers. Traditional batik techniques gradually meet the needs of modern society, which is not only conducive to minority cultural heritage, but also conducive to fashion design innovation.

\section{Overview of Related Batik}

Batik is also known as "wax Valerian", is an ancient dyeing technique minorities. Batik is a wax knife dipped in molten wax painted flowers on a cloth with indigo dip, both dye to the wax, showing a variety of patterns on cloth blue white or blue and white flowers, while in the dip, as the anti-agent natural wax cracking, make the fabric presents special "ice lines", especially with charm. Using this method dyed pattern used in the life of appliances and clothing, having fun and 
decorative arts value. Batik art originated in the Qin and Han Dynasty, popular in the Six Dynasties. Due to open clothing, batik Tang Dynasty gradually loved by the royal family, after the majority of civil suit, gradual decline in the Song Dynasty. Batik later was passed neighboring countries and widely popular, such as Japan, Indonesia and other countries. Because of the many ethnic minorities in Southwest China, formed a large batik art form and style, rich in content. Batik process is mainly the use of exaggeration, simple, abstract patterns and lines to describe the scene Miao people's production and life, war, formed a unique printing techniques, the well between the various ethnic and tribal culture from the deep aspects linked. Batik Art rustic, naive, rough, strong, contains the infinite charm, which not only has strong national colors, and adapted to the needs of modern life, for the modern aesthetic.

\section{The Process of Batik Art Style}

Hmong batik process is mainly used to record life, production, war and sacrifice other activities, colorful patterns, the performance practices include impressionistic and realistic two kinds. Hmong batik pattern drawn diverse ways, have learned from ancient legend, there are flowers and birds drawn from nature, the whole pattern looks simple, the atmosphere. In the batik process, dragon and bird are the most widely used. Dragon Hmong batik process is the most widely used kind of pattern that is mainly from the myths and legends, coupled with people's reverence for nature, and then take a certain level of abstraction freehand, forming a distinctive pattern in printing life of appliances and clothing in order to bring fortune. Different batik in various regions, it is in the form of dragons are also varied, with abstract shape curve constructed, there are specific image of the birds first snake. Bird is Hmong phoenix, it is widely used in the art of batik, which is formed with the Hmong living in the mountains of the natural environment is closely related to the significance, also related to Hmong custom bird lovers. Miao Yu Wen in the far-reaching implication, it placed the good wishes of the Hmong people of many sons. In addition to the extensive use of three patterns, butterfly patterns and geometric patterns are also frequently used their skills in batik patterns. Throughout the modeling, the parent is a big butterfly surrounded by diverse lines, modified, demonstrates the vigor. Geometric patterns mainly Hmong people to express reverence for nature and a recording of the laws of nature, etc., the vast amount includes a sawtooth pattern, Raven, cross pattern and so on.

Batik is blue and white color, represents hope, purity, wisdom. On the basis of the main colors of blue and white, and to be indigo, light blue, dark blue and other colors adorn the entire batik color rich layering, no significant monotonous. Blue and white is the color of the sky, can bring serenity, profound feelings, so the whole picture simple, elegant. Divided by blue white color, but also to be colored batik, so that the entire screen full of changes, so that the picture lively. In the process of batik, the blue color and the color printing is used alternately or in blue on a white base fabric. Hmong colored batik process in primarily using cranberry juice, orange juice yellow, indigo and the like.

\section{The Batik Technique in Modern Fashion Design}

Batik is one of the oldest printing process, with a rich cultural heritage, is one of the important traditional culture, heritage of the Miao it rich culture, many organizations increasing emphasis on its heritage and development. With the prosperity and development of the apparel industry, a variety of clothing design elements are widely explore and use. Batik art carries a rich cultural characteristics, be applied to modern clothing designers, and gives endless visual feast. 
In the process of costume design, style, color, fabric, etc. are important design elements. Higher batik fabric requirements need to be smooth, easy to penetrate, high temperature. Cotton, hemp, silk fabric is the most commonly used. With the continuous development of technology, a variety of new fabrics have been developed in the future will have more batik fabric choices. Batik process unique patterns and colors, rich patterns drawn, emphasizing the image of interest. Costume design batik fabrics and fabrics deployment must be coordinated with each other, both have a contrast but also harmony, variety of fabrics of desired thickness, elasticity, hardness should be consistent. The height of the development of modern printing techniques, so batik process has been greatly improved, so that color colorful batik work, they can always adjust the tint of the batik fashion color changes. But batik after the millennium, are blue and white tones, with a rich cultural heritage, in the clothing design engineering, to be innovative to traditional techniques, more is to be the inheritance of traditional culture, it should follow the traditional batik colors blue-based. Designers in the design process, we should understand the meaning of color batik process, to be applied flexibly, timely join the modern color, achieve harmony and unity of effect. Batik patterns are Hmong people gather thousands of years of wisdom and faith, steeped in history, complex and diverse patterns. In practice, modern dress, it should be properly abandoned old ingredients do not meet modern aesthetic, to be innovative and use. Batik art to seek its own continuous development, must comply with the development trend of the times, focusing on the development of printing and dyeing technology, to increase productivity and allow modern technology to replace the original manual processing, such as embroidery machines, printing machines, digital printing patterns, crystal iron tablets, etc., thereby expanding the batik process in the new era of living space.

\section{Conclusion}

Batik ethnic connotation has a rich cultural heritage and it is one of the representatives of the valuable intangible cultural heritage and ethnic culture. Hmong batik accumulation of years of wisdom, in the fashion design process, on the one hand to make use of modern design, on the other hand, we have to save the essence of Hmong batik process. Depending on the needs of consumers to design different styles of clothing, increase batik audience. In order to seek long-term development of batik, the traditional art and modern aesthetic needs to be combined together.

\section{Reference}

[1] Chen Lan. Use Guizhou Miao Batik Design Patterns In Modern Fashion Design [J]. Literary Life: The Xunkan, 2011, (8): 154-155.

[2] Zhang Yeling. Innovation and Application [J]. Batik in Fashion Design Textile Science, 2013,54 (3): 11-13.

[3] Liu Yang. Decorative Elements Study of Guizhou Batik Fan Back in the Clothing and the Application [D]. Beijing Institute of Clothing, 2015.

[4] Yang Jun. Batik Clothing Brand Design Characteristics [J]. Jiaxing College, 2003,15 (5): 123-124. 